\title{
Responses of Tomato to Potassium Rates in a Calcareous Soil
}

\author{
Qiang Zhu' ${ }^{1}$ and Monica Ozores-Hampton \\ Southwest Florida Research and Education Center, University of Florida, \\ Institute of Food and Agricultural Sciences, Immokalee, FL 34142
}

\section{Yuncong Li}

Tropical Research and Education Center, University of Florida, Institute of Food and Agricultural Sciences, Homestead, FL 33031

\section{Kelly Morgan \\ Southwest Florida Research and Education Center, University of Florida, Institute of Food and Agricultural Sciences, Immokalee, FL 34142}

\section{Guodong Liu}

Horticultural Sciences Department, University of Florida, Gainesville, FL 32611

\section{Rao S. Mylavarapu \\ Soil and Water Sciences Department, University of Florida, Gainesville, FL 32611}

Additional index words. leaf tissue potassium concentration, plant biomass, marketable yield, postharvest quality, regression models

\begin{abstract}
Florida produces the most vegetables in the United States during the winter season with favorable weather conditions. However, vegetables grown on calcareous soils in Florida have no potassium (K) fertilizer recommendation. The objective of this study was to evaluate the effects of $K$ rates on leaf tissue $K$ concentration (LTKC), plant biomass, fruit yield, and postharvest quality of tomatoes (Solanum lycopersicum L.) grown on a calcareous soil. The experiment was conducted during the winter seasons of 2014 and 2015 in Homestead, FL. Potassium fertilizers were applied at rates of 0, 56, 93, 149,186 , and $223 \mathrm{~kg} \cdot \mathrm{ha}^{-1}$ of $\mathrm{K}$ and divided into preplant dry fertilizer and fertigation during the season. No deficiency of LTKC was found at 30 days after transplanting (DAT) in both years. Potassium rates lower than $149 \mathrm{~kg} \cdot \mathrm{ha}^{-1}$ resulted in deficient LTKC at 95 DAT in 2014. No significant responses to $K$ rates were observed in plant (leaf, stem, and root combined) dry weight biomass at all the sampling dates in both years. However, at 95 DAT, fruit dry weight biomass increased with increasing $K$ rates to 130 and $147 \mathrm{~kg} \cdot \mathrm{ha}^{-1}$, reaching a plateau thereafter indicated by the linear-plateau models in 2014 and 2015, respectively. Predicted from quadratic and linear-plateau models, K rates of 173 and $178 \mathrm{~kg} \cdot \mathrm{ha}^{-1}$ were considered as the optimum rates for total season marketable yields in 2014 and 2015, respectively. Postharvest qualities, including fruit firmness, pH, and total soluble solids (TSS) content, were not significantly affected by $K$ rates in both years. Overall, $K$ rate of $178 \mathrm{~kg} \cdot \mathrm{ha}^{-1}$ was sufficient to grow tomato during the winter season in calcareous soils with 78 to $82 \mathrm{mg} \cdot \mathrm{kg}^{-1}$ of ammonium bicarbonatediethylenetriaminepentaacetic acid (AB-DTPA)-extracted $\mathrm{K}$ in Florida.
\end{abstract}

Florida ranked first nationally in fresh market tomato (Solanum lycopersicum L.) production with 13,030 ha harvested and a total value of US \$453 million in 2015 (U.S. Department of Agriculture, 2016). Potassium is an essential element in tomato production and plays an important role in transporting and accumulating carbohydrates and organic acids to guarantee normal plant

\footnotetext{
Received for publication 10 Jan. 2017. Accepted for publication 12 Mar. 2017.

This research was partially funded by the Florida Department of Agriculture and Consumer Services (FDACS).

${ }^{1}$ Corresponding author. E-mail: qiangzhuuf@ gmail.com.
}

growth and high fruit quality (Huang and Snapp, 2009). Adequate K uptake has been shown to enhance tomato fruit size, color, flavor, and peel thickness, and reduce the severity of diverse fruit physiological disorders (e.g., uneven and blotchy ripening, irregular shape and hollow fruit, yellow shoulder, gray wall, and decreased lycopene content) (Bose et al., 2006; Hartz et al., 1999, 2002; Havlin et al., 2014).

Potassium fertilizer recommendations based on preplant soil test $\mathrm{K}$ (STK) results are critical in lowering input costs without reducing marketable yield and fruit quality (Ozores-Hampton et al., 2012b). Florida has $\mathrm{K}$ recommendations ranging from 0 to $139 \mathrm{~kg} \cdot \mathrm{ha}^{-1}$ for tomato in acid-mineral soils with high $\left(>60 \mathrm{mg} \cdot \mathrm{kg}^{-1}\right)$ to low $\left(\leq 35 \mathrm{mg} \cdot \mathrm{kg}^{-1}\right)$ interpretation categories using Mehlich-3 extractant (Freeman et al., 2014b). According to the recommendation, supplemental K application is optional when there are leaching rainfalls (a rainfall amount of $76 \mathrm{~mm}$ in $3 \mathrm{~d}$ or $102 \mathrm{~mm}$ in $7 \mathrm{~d})$, deficient LTKC $\left(<25 \mathrm{~g} \cdot \mathrm{kg}^{-1}\right)$, or extended harvests (Freeman et al., 2014b). Nonetheless, tomato growers tend to use K rates as high as $604 \mathrm{~kg} \cdot \mathrm{ha}^{-1}$ to avoid potential yield or quality losses (Ozores-Hampton et al., 2012b). In acid-mineral soils with low level of STK, optimal K rates ranging from 270 to $360 \mathrm{~kg} \cdot \mathrm{ha}^{-1}$ could produce maximum tomato marketable yield with seepage irrigation (Csizinszky, 1999; Ozores-Hampton et al., 2012b).

Limited information about optimal $\mathrm{K}$ rates is available for tomatoes grown on calcareous soils in Florida. A typical Florida calcareous soil is classified as Krome series (loamy-skeletal, carbonatic, hypothermic, lithic, udorthents) by the National Cooperative Soil Survey with 24,000 ha (U.S. Department of Agriculture, 1996). These soils usually have a $15-$ to $20-\mathrm{cm}$ rock-plowed surface layer above a porous limestone bedrock with high $\mathrm{pH}$ (7.4-8.4), high calcium carbonate content (300-940 $\left.\mathrm{g} \cdot \mathrm{kg}^{-1}\right)$, and low organic matter content $\left(<20 \mathrm{~g} \cdot \mathrm{kg}^{-1}\right)(\mathrm{Li}$, 2015). The only available study about $\mathrm{K}$ rates in Florida calcareous soils was from Carranza et al. (1996), which reported no tomato-yield responses to $\mathrm{K}$ supplies with medium-to-high AB-DTPA-extracted K. The numerical soiltest interpretations with AB-DTPA or other extractants, however, were not provided. Because no soil-test interpretations exist based on effective soil-test extractants, $\mathrm{K}$ recommendations are not available for vegetables grown on soils with those chemical characteristics. Therefore, the objective of this experiment was to determine the responses of tomato, including LTKC, plant biomass, fruit yield, and postharvest quality, to $\mathrm{K}$ rates in a calcareous soil in Florida.

\section{Materials and Methods}

The study was conducted in the same field at the University of Florida (UF)/Tropical Research and Education Center's research farm, Homestead, FL, during the winter seasons of 2014 (from 29 Oct. 2014 to 24 Mar. 2015 ) and 2015 (from 15 Oct. 2015 to 16 Feb. 2016). The field $\left(25^{\circ} 30^{\prime} 47^{\prime \prime} \mathrm{N} / 80^{\circ} 30^{\prime} 3^{\prime \prime} \mathrm{W}\right)$, which had been primarily used to grow goosegrass (Eleusine indica) over 10 years, was plowed, and the grasses were incorporated into the soil. Sorghum-sudangrass (Sorghum bicolor $\times S$. bicolor var. sudanese) was then planted on 28 Aug. 2014, and the aboveground portions were moved out from the field on 30 Sept. 2014 for the purpose of removing parts of available nutrients from the soil. From the end of 2014 season to the beginning of 2015 season, the field was in fallow. The pH, EC, carbonate concentration, organic matter, nitrate-nitrogen $\left(\mathrm{NO}_{3}-\mathrm{N}\right)$, ammonium-nitrogen $\left(\mathrm{NH}_{4}-\mathrm{N}\right)$, total $\mathrm{K}$, Mehlich-3-extracted $\mathrm{K}$, and AB-DTPA-extracted phosphorus (P), K, iron 
$(\mathrm{Fe})$, zinc $(\mathrm{Zn})$, and manganese $(\mathrm{Mn})$ of soil samples collected before applying fertilizers in the growing season of 2014 were $7.8,248.2 \mu \mathrm{S} \cdot \mathrm{cm}^{-1}, 379.3 \mathrm{~g} \cdot \mathrm{kg}^{-1}, 56.9 \mathrm{~g} \cdot \mathrm{kg}^{-1}$, $22.3 \mathrm{mg} \cdot \mathrm{kg}^{-1}, 7.2 \mathrm{mg} \cdot \mathrm{kg}^{-1}, 1422.7 \mathrm{mg} \cdot \mathrm{kg}^{-1}$, $112.2 \mathrm{mg} \cdot \mathrm{kg}^{-1}, 14.7 \mathrm{mg} \cdot \mathrm{kg}^{-1}, 81.5 \mathrm{mg} \cdot \mathrm{kg}^{-1}, 6.3$ $\mathrm{mg} \cdot \mathrm{kg}^{-1}, 6.7 \mathrm{mg} \cdot \mathrm{kg}^{-1}$, and $11.1 \mathrm{mg} \cdot \mathrm{kg}^{-1}$, respectively. The content of gravel $(>2 \mathrm{~mm})$ was between $54.3 \%$ and $72.2 \%$, and soil clay, silt, and sand were $8.4 \%, 13.2 \%$, and $78.4 \%$, respectively. In the growing season of 2015, preplant Mehlich-3- and AB-DTPA-extracted $\mathrm{K}$ averaged at 99.0 and $78.0 \mathrm{mg} \cdot \mathrm{kg}^{-1}$, respectively. The initial STK levels for both years were categorized as high $\left(>60 \mathrm{mg} \cdot \mathrm{kg}^{-1}\right)$ and medium (61-120 mg. $\mathrm{kg}^{-1}$ ) using the Mehlich-3 interpretation for Florida acid-mineral soils (Freeman et al., 2014b) and AB-DTPA interpretation for Colorado calcareous soils (Soltanpour, 1985), respectively.

Treatments were arranged in a randomized complete block design with four replications. On 29 Oct. 2014 and 15 Oct. 2015, beds were formed $183 \mathrm{~cm}$ center to center, $20 \mathrm{~cm}$ high, and $91 \mathrm{~cm}$ wide across the top. Each plot was $9.1 \mathrm{~m}$ long and included three adjacent beds. There were six $\mathrm{K}$ rates with $0,56,93,149$, 186 , and $223 \mathrm{~kg} \cdot \mathrm{ha}^{-1}$ of $\mathrm{K}$. Nitrogen $(\mathrm{N})$ and $\mathrm{P}$ were applied at constant rates for all treatments with $224 \mathrm{~kg} \cdot \mathrm{ha}^{-1}$ of $\mathrm{N}$ and $78 \mathrm{~kg} \cdot \mathrm{ha}^{-1}$ of P. Fertilizers application rates were selected based on the recommendations for tomatoes grown on Florida acid-mineral soils as well as a previous pot study using soils from the same experimental site ( $\mathrm{Zhu}$ et al., 2016). Preplant dry fertilizers, including all $\mathrm{P}, 25 \%$ of $\mathrm{N}$, and portions of $\mathrm{K}$ fertilizers $(0,0,37$, 56,93 , and $130 \mathrm{~kg} \cdot \mathrm{ha}^{-1}$ from each rate, respectively), were banded $8 \mathrm{~cm}$ below and $15 \mathrm{~cm}$ to each side of the bed center. The remaining $\mathrm{N}$ and $\mathrm{K}(0,56,56,93,93$, and $93 \mathrm{~kg} \cdot \mathrm{ha}^{-1}$ from each rate, respectively) were supplied weekly via injection (Table 1). Sources of dry fertilizers were urea (46-0-0), triple superphosphate (0-46-0), and potassium sulfate $(0-0-52)$; liquid fertilizers included

Table 1. Potassium (K) rates and placement for tomatoes grown in 2014 and 2015 winter seasons in Homestead, FL.

\begin{tabular}{|c|c|c|c|c|}
\hline \multirow{4}{*}{$\begin{array}{l}\text { Total K } \\
\text { rate }^{\mathrm{z}}\end{array}$} & \multicolumn{4}{|c|}{ Days after transplanting } \\
\hline & 0 & $0-30$ & $30-60$ & $60-95$ \\
\hline & $\overline{\text { Dry fertilizer }}$ & \multicolumn{3}{|c|}{ Fertigation } \\
\hline & \multicolumn{4}{|c|}{$\left(\mathrm{kg} \cdot \mathrm{ha}^{-1}\right)$} \\
\hline 2014 & & & & \\
\hline 0 & 0 & 0 & 0 & 0 \\
\hline 56 & 0 & 12 & 25 & 19 \\
\hline 93 & 37 & 12 & 25 & 19 \\
\hline 149 & 56 & 21 & 41 & 31 \\
\hline 186 & 93 & 21 & 41 & 31 \\
\hline 223 & 130 & 21 & 41 & 31 \\
\hline \multicolumn{5}{|l|}{2015} \\
\hline 0 & 0 & 0 & 0 & 0 \\
\hline 56 & 0 & 4 & 24 & 28 \\
\hline 93 & 37 & 4 & 24 & 28 \\
\hline 149 & 56 & 6 & 41 & 46 \\
\hline 186 & 93 & 6 & 41 & 46 \\
\hline 223 & 130 & 6 & 41 & 46 \\
\hline
\end{tabular}

${ }^{\mathrm{z}}$ Fertilizer source: potassium sulfate $(0-0-52)$ was used for dry fertilizer, and LoKomotive (2-0-25) was used for fertigation.
N-PACT (26-0-0; Loveland Products Inc., Loveland, $\mathrm{CO})$ and LoKomotive (2-0-25; Loveland Products Inc., Loveland, CO). After preplant fertilizer application, beds were sprayed with Sandea herbicide (Gowan Company, Yuma, AZ) and covered with polyethylene mulch (Guardian Standard white on black; Guardian AgroPlastics Inc., Florence, SC). Meanwhile, four drip tapes $(20 \mathrm{~cm}$ emitter spacing with a flow rate of $4.2 \mathrm{~L} \mathrm{~min}^{-1} 100 \mathrm{~m}^{-1}$ at $55 \mathrm{kPa}$; T-Systems International Inc., San Diego, CA) were placed on each bed; two of them were used for irrigation and the other two for fertigation. On 6 Nov. 2014 and 23 Oct. 2015, tomato seedlings (cv. Ridgerunner; Syngenta, Greensboro, NC) were transplanted to the bed center with $46 \mathrm{~cm}$ between plants and a population of $11,960 \mathrm{plant} / \mathrm{ha}$. Pest control and irrigation management were conducted following UF/Institute of Food and Agricultural Sciences recommendations (Freeman et al., 2014a). Weather data were obtained from a Florida Automated Weather Network station located $100 \mathrm{~m}$ away from the experimental field.

At 30, 60, and $95 \mathrm{DAT}$, five to six of the most recently matured whole leaves and petioles were collected from each plot to measure LTKC. Meanwhile, one whole plant from each plot was collected, and the leaf, stem, root, and fruit were separated to measure biomass of each tissue. All plant samples were oven-dried at $70{ }^{\circ} \mathrm{C}$ until constant weight was achieved. After drying, leaf tissue samples were ground to pass a 0.84-mm sieve, digested by hydrochloric acid (Mylavarapu et al., 2014), and analyzed for K through Inductively Coupled Plasma Optical Emission Spectroscopy (Optima 7000 DV ICP-OES; PerkinElmer Inc., Waltham, MA). Tomato fruits from 10 plants located in the middle bed of each plot were harvested at mature-green stage at 111,125 , and 138 DAT in 2014 and 88, 102, and 116 DAT in 2015 as the first, second, and third harvest, respectively. Marketable fruit were weighed separately and categorized as extra-large (diameter greater than $7 \mathrm{~cm}$ ), large (diameter from 6.4 to $7.1 \mathrm{~cm}$ ), and medium (diameter from 5.7 to $6.4 \mathrm{~cm}$ ) fruits (U.S. Department of Agriculture, 1997). Unmarketable fruits were recognized based on the presence of the rough blossom-end scar (catface), cracking (concentric and radial), off-shape, zipper scars, sunscald, and other viral and pest damages (Barten et al., 1992; Olson and Freeman, 2016). At the first harvest, 10 mature-green fruits from each plot were collected, treated with ethylene, and ripened at $20{ }^{\circ} \mathrm{C}$ with $85 \%$ to $90 \%$ relative humidity in DiMare's packing house (Homestead, FL). After reaching the breaker stage, tomatoes were moved out of the packing house and ripened at room temperature $\left(23\right.$ to $\left.24{ }^{\circ} \mathrm{C}\right)$ to the table-ripe stage (defined as "the point at which redripe tomatoes become noticeably softer when pressure is applied with thumb and fingertips to the equatorial region of each fruit") for postharvest evaluation (Frasca and Ozores-Hampton, 2014). Four fruit from each plot were tested for fruit deformation using an 11-mm probe, and 1-kg force was applied to the fruit equator area for $5 \mathrm{~s}$ by a portable digital firmness tester (Model C125EB; Mitutoyo Corp., Aurora, IL); exterior fruit color was measured on the same four fruit using a 1 to 6 scale, where $1=$ green and $6=$ red (U.S. Department of Agriculture, 1997); one-fourth of each of the four fruit was used to measure TSS at $20{ }^{\circ} \mathrm{C}$ and $\mathrm{pH}$ using a portable refractometer (Fisher Catalog Number 13-946-26; Fisher Scientific, Pittsburgh, PA) and a $\mathrm{pH}$ meter (Accumet AR 60; Fisher Scientific), respectively.

Leaf tissue $\mathrm{K}$ concentrations, plant biomass, and tomato yield were analyzed separately for each year because of the differences in fertigation schedules and weather conditions during the two seasons. The significance of the year by K-rate interaction was determined in postharvest quality assessments. If no significant interaction was found, the data from each year were combined for analysis. All the data were shown as means of four replications and first subjected to analysis of variance (ANOVA) using SAS (Version 9.2; SAS Institute Inc., Cary, NC). When F-test showed statistical significance in ANOVA $(P<0.05)$, the responses to $\mathrm{K}$ rates were analyzed using four regression models: linear $(y=a+b x)$, quadratic $\left(y=a+b x+c x^{2}\right)$, linear-plateau ( $y=a+b x$ if $x<$ critical rate, $y=$ plateau if $x>$ critical rate), and quadraticplateau $\left(y=a+b x+c x^{2}\right.$ if $x<$ critical rate, $y=$ plateau if $x>$ critical rate), where $y$ was the response, $x$ was $\mathrm{K}$ rate, and $a, b$, and $c$ were constants. The accumulated $\mathrm{K}$ rates at 30,60 , and 95 DAT were used for regression at the respective sampling dates of LTKC and biomass. The model with $P<0.05$, lower mean square error, and higher coefficient of determination $\left(r^{2}\right)$ was selected as the best-fit regression model (Ozores-Hampton et al., 2012a). The critical rates at which linear line intersected with plateau in the linear-plateau model and the maximum-dependent variable occurred in the quadratic model were considered as the optimum rates.

\section{Results}

During the 2014 and 2015 seasons, average $60-\mathrm{cm}$ air temperatures were 20.3 and $21.7^{\circ} \mathrm{C}$, respectively. From 0 to 60 DAT, daily minimum and maximum air temperatures averaged at 15.2 and $26.5^{\circ} \mathrm{C}$ in 2014 and at 20.1 and $28.6^{\circ} \mathrm{C}$ in 2015 , respectively. The total rainfall in the 2014 season was $129.6 \mathrm{~mm}$ without a leaching rainfall event. In the 2015 season, total rainfall was $563.9 \mathrm{~mm}$, and two leaching rainfall events occurred in December.

At 30 DAT, LTKCs in both years were higher than the deficient value of $25 \mathrm{~g} \cdot \mathrm{kg}^{-1}$ (Table 2). In 2014, LTKC at 60 DAT was above the deficient value with $\mathrm{K}$ rates from 0 to $186 \mathrm{~kg} \cdot \mathrm{ha}^{-1}$, but LTKC was higher than the sufficient value of $40 \mathrm{~g} \cdot \mathrm{kg}^{-1}$ at $223 \mathrm{~kg} \cdot \mathrm{ha}^{-1}$; at $95 \mathrm{DAT}, \mathrm{K}$ rates below $149 \mathrm{~kg} \cdot \mathrm{ha}^{-1}$ resulted 
in deficient levels of LTKC. At both 60 and 95 DAT in 2015, deficient LTKCs were detected in plants without $\mathrm{K}$ fertilization, and above-sufficient levels of LTKC were observed with $\mathrm{K}$ rates of 186 and $223 \mathrm{~kg} \cdot \mathrm{ha}^{-1}$. At 95 DAT, the responses of LTKC to $\mathrm{K}$ rates were predicted by the quadratic and linear-plateau models with critical $\mathrm{K}$ rates of 192 and $205 \mathrm{~kg} \cdot \mathrm{ha}^{-1}$ in 2014 and 2015 , respectively.

No significant responses were found in plant biomass (leaf, stem, and root combined) at 30,60, and 95 DAT and in fruit biomass at 60 DAT in both years (Table 3). At 95 DAT, plant biomasses were similar between the 2 years, but the fruit biomass in 2014 was higher than that in 2015 with respective $\mathrm{K}$ rates. The proportion of fruit in total biomass (plant and fruit) ranged from $51 \%$ to $60 \%$ and from $34 \%$ to $39 \%$ with an average of $55 \%$ and $37 \%$ at 95 DAT in 2014 and 2015, respectively. The relationships between fruit biomass and $\mathrm{K}$ rates were described by linearplateau models with critical $\mathrm{K}$ rates of 130 and $147 \mathrm{~kg} \cdot \mathrm{ha}^{-1}$ at $95 \mathrm{DAT}$ in 2014 and 2015, respectively. At 95 DAT, the total biomass increased quadratically with increasing $\mathrm{K}$ rate and reached a maximum at $187 \mathrm{~kg} \cdot \mathrm{ha}^{-1}$ in 2014 , but in 2015 , the total biomass was not significantly affected by $\mathrm{K}$ rates.

In 2014, no significant responses to $\mathrm{K}$ rates were found in marketable and unmarketable yields in the first harvest (Table 4). In the first and second combined harvest, extra-large fruit and total marketable yields were predicted by quadratic models with optimum K rate of $160 \mathrm{~kg} \cdot \mathrm{ha}^{-1}$. Total season extra-large fruits accounted for $81 \%$ to $84 \%$ of the total season marketable yields (TSMY) (all size categories in three harvests combined) with $67 \%$ to $79 \%$ of the extra-large fruits from the first harvest. Potassium rates that produced the maximum total season extra-large fruits and TSMY were 159 and $173 \mathrm{~kg} \cdot \mathrm{ha}^{-1}$, respectively, predicted from quadratic models. Total season large and medium fruits and unmarketable yields were not significantly affected by $\mathrm{K}$ rates.

In 2015, marketable and unmarketable yields were not significantly affected in the first harvest (Table 4). In the first and second combined harvest, the medium fruit yield increased linearly with increasing $\mathrm{K}$ rates. Total season extra-large, large, and medium

Table 2. Leaf tissue potassium (K) concentration in response to K rates for tomatoes grown in 2014 and 2015 winter seasons in Homestead, FL.

\begin{tabular}{|c|c|c|c|c|c|c|}
\hline \multirow[b]{3}{*}{ Total $\mathrm{K}$ rate } & \multicolumn{6}{|c|}{ Days after transplanting } \\
\hline & \multicolumn{2}{|c|}{30} & \multicolumn{2}{|c|}{60} & \multicolumn{2}{|c|}{95} \\
\hline & 2014 & 2015 & 2014 & 2015 & 2014 & 2015 \\
\hline$\overline{\left(\mathrm{kg} \cdot \mathrm{ha}^{-1}\right)}$ & \multicolumn{6}{|c|}{$\left(\mathrm{g} \cdot \mathrm{kg}^{-1}\right)$} \\
\hline$\overline{0}$ & 32.8 & 26.6 & 29.4 & 21.8 & 9.9 & 15.4 \\
\hline 56 & 29.9 & 29.9 & 27.3 & 27.8 & 13.0 & 22.9 \\
\hline 93 & 29.0 & 31.9 & 38.7 & 32.0 & 17.5 & 20.9 \\
\hline 149 & 35.9 & 34.1 & 38.7 & 36.3 & 24.6 & 37.0 \\
\hline 186 & 33.5 & 33.0 & 35.2 & 44.4 & 21.4 & 41.4 \\
\hline 223 & 36.1 & 39.3 & 42.5 & 42.8 & 20.8 & 43.1 \\
\hline$P$ value & 0.19 & 0.01 & 0.002 & 0.001 & 0.02 & 0.001 \\
\hline Significance $^{z}$ & NS & $* *$ & $* *$ & $* * *$ & $*$ & $* * *$ \\
\hline Regression $^{\mathrm{y}}$ & - & $\mathrm{L}$ & $\mathrm{L}$ & $\mathrm{L}$ & Q & LP \\
\hline Coefficient of determination & - & 0.51 & 0.45 & 0.88 & 0.60 & 0.89 \\
\hline Optimum rate & - & - & - & - & 192 & 205 \\
\hline Adequate range $^{\mathrm{x}}$ & \multicolumn{2}{|c|}{$25.0-40.0$} & \multicolumn{2}{|c|}{$25.0-40.0$} & \multicolumn{2}{|c|}{$20.0-40.0$} \\
\hline
\end{tabular}

$\mathrm{z}_{\mathrm{NS}}, *, * * * * *$ Nonsignificant or significant at $P<0.05,0.01$, and 0.001 , respectively.

${ }^{\mathrm{y}} \mathrm{L}=$ linear; $\mathrm{Q}=$ quadratic; $\mathrm{LP}=$ linear-plateau.

${ }^{\mathrm{x}}$ Source: Hochmuth et al. (2012).

Table 3. Plant (leaf, stem, and root combined), fruit, and total (plant and fruit) dry weight biomass in response to potassium (K) rates for tomatoes grown in 2014 and 2015 winter seasons in Homestead, FL.

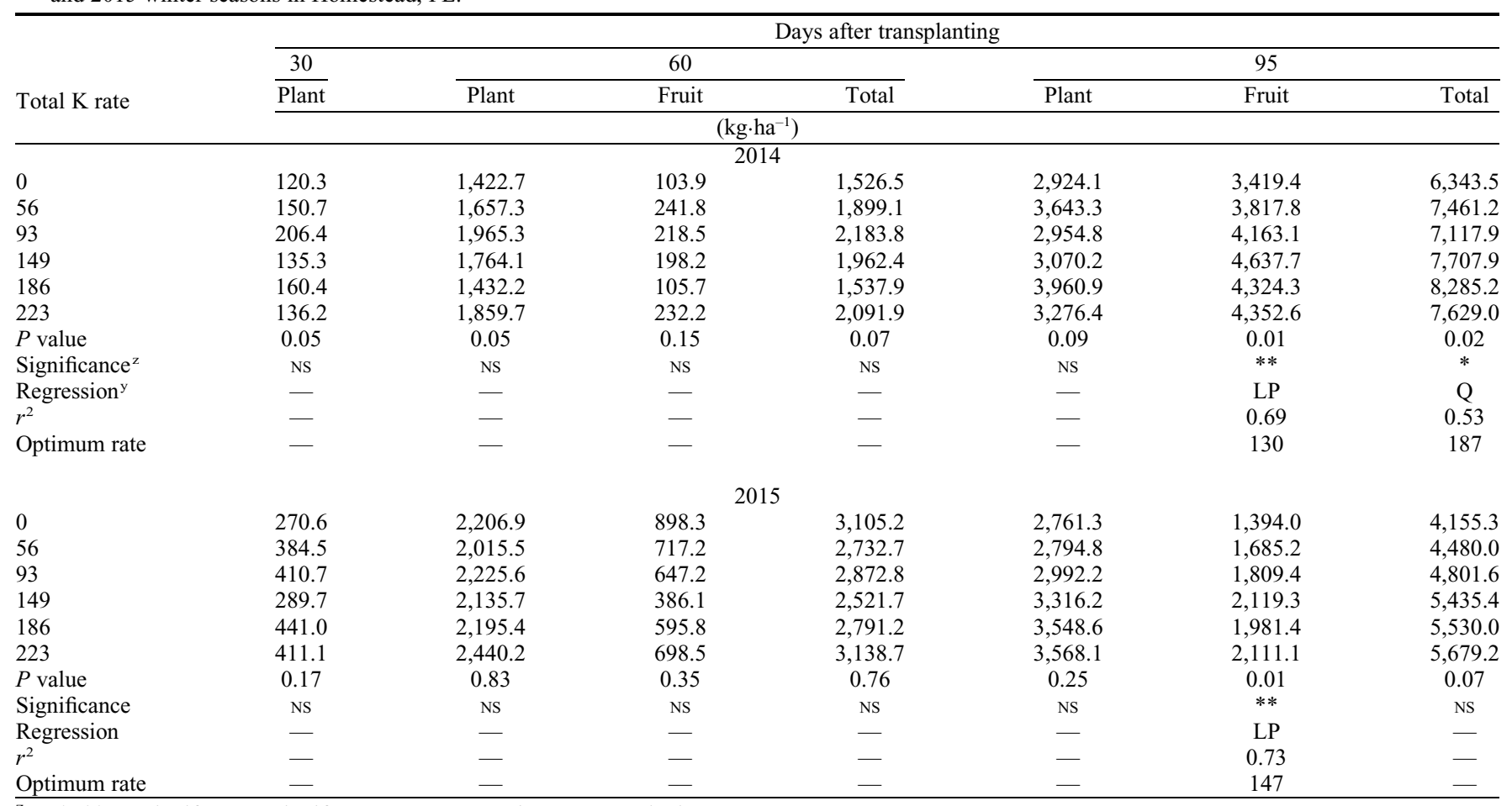

$\mathrm{z}_{\mathrm{NS}}, *, * *$ Nonsignificant or significant at $P<0.05$ and 0.01 , respectively.

${ }^{\mathrm{y}} \mathrm{LP}=$ linear-plateau; $\mathrm{Q}=$ quadratic; $r^{2}=$ coefficient of determination. 
fruits accounted for $41 \%$ to $61 \%, 21 \%$ to $30 \%$, and $17 \%$ to $30 \%$ of TSMY, respectively. Response of total season medium-fruit yield was predicted by the linear model, whereas the total season large-fruit yield and TSMY were predicted by the linearplateau model with critical $\mathrm{K}$ rates of 153 and $178 \mathrm{~kg} \cdot \mathrm{ha}^{-1}$, respectively. Total season extra-large fruit and unmarketable yields were not significantly affected by K rates.

No significant interactions between $\mathrm{K}$ rates and years were found for tomato postharvest-quality assessments except for the exterior color (Table 5). In 2014, no significant differences were observed in tomato exterior color, whereas in 2015, the response of tomato exterior color to $\mathrm{K}$ rates was described by a quadratic model with an optimum $\mathrm{K}$ rate of $138 \mathrm{~kg} \cdot \mathrm{ha}^{-1}$. Fruit deformation, $\mathrm{pH}$, and TSS content were not significantly affected by $\mathrm{K}$ rates and each averaged at $2.6 \mathrm{~mm}, 4.3$, and $3.8^{\circ}$ Brix, respectively.

\section{Discussion}

With higher air temperatures at the early stage of crop development during the 2015 season, plants exhibited a faster growth rate, which resulted in a $22 \mathrm{~d}$ shorter growing season compared with the 2014 season. Hatfield and Prueger (2015) indicated that shorter life cycle of nonperennial crops shortened reproductive duration and thus reduced yield potential. In addition, extremely high rainfall accumulation was observed in Dec. 2015. Ozores-Hampton and McAvoy (2015) found that temperature above $29^{\circ} \mathrm{C}$ during the day or above $21{ }^{\circ} \mathrm{C}$ at night together with high rainfall could adversely affect pollination and tomato fruit development. Owing to the adverse growth conditions, therefore, less fruit dry weight biomass at 95 DAT and TSMY were obtained in 2015 than in 2014 with respective $\mathrm{K}$ rates.

Irrespective of various preplant dry fertilizer rates from 0 to $130 \mathrm{~kg} \cdot \mathrm{ha}^{-1}$, at $30 \mathrm{DAT}$ of both years, the LTKCs were above the deficient value, and plant biomasses were not significantly affected, suggesting that initial soil $\mathrm{K}$ levels were adequate for early plant

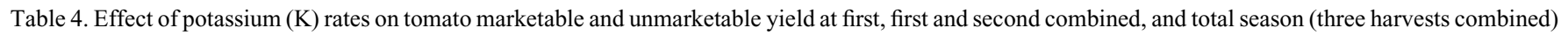
harvests in 2014 and 2015 winter seasons in Homestead, FL.

\begin{tabular}{|c|c|c|c|c|c|c|c|c|c|c|c|c|c|c|c|}
\hline \multirow[b]{2}{*}{$\mathrm{K}$ rate } & \multicolumn{5}{|c|}{ First harvest } & \multicolumn{5}{|c|}{ First and second harvest } & \multicolumn{5}{|c|}{ Total season harvest } \\
\hline & $\mathrm{XL}^{\mathrm{z}}$ & $\mathrm{L}$ & & $\mathrm{T}$ & $\mathrm{U}$ & $\mathrm{XL}$ & $\mathrm{L}$ & $\mathrm{M}$ & $\mathrm{T}$ & $\mathrm{U}$ & $\mathrm{XL}$ & $\mathrm{L}$ & $\mathrm{M}$ & $\mathrm{T}$ & $\mathrm{U}$ \\
\hline$\left(\mathrm{kg} \cdot \mathrm{ha}^{-1}\right)$ & \multicolumn{15}{|c|}{$\left(\mathrm{t} \cdot \mathrm{ha}^{-1}\right)$} \\
\hline & & & & & & & 2014 & & & & & & & & \\
\hline 0 & 37.3 & 2.4 & 0.3 & 40.0 & 12.8 & 48.2 & 6.1 & 1.3 & 55.6 & 19.9 & 49.1 & 7.6 & 4.1 & 60.8 & 26.5 \\
\hline 56 & 45.2 & 4.3 & 0.2 & 49.8 & 12.3 & 55.6 & 7.1 & 1.3 & 63.9 & 19.9 & 57.3 & 9.0 & 3.5 & 69.8 & 26.5 \\
\hline 93 & 50.3 & 4.2 & 0.3 & 54.8 & 14.6 & 64.2 & 8.2 & 1.1 & 73.6 & 26.3 & 65.8 & 9.4 & 2.7 & 77.9 & 31.6 \\
\hline 149 & 48.3 & 3.3 & 0.0 & 51.6 & 12.6 & 63.8 & 6.7 & 0.9 & 71.5 & 23.2 & 66.6 & 9.4 & 3.7 & 79.7 & 33.8 \\
\hline 186 & 49.2 & 3.7 & 0.1 & 53.1 & 11.0 & 71.6 & 8.1 & 1.3 & 81.0 & 18.8 & 74.1 & 11.0 & 4.3 & 89.3 & 26.3 \\
\hline 223 & 44.1 & 4.2 & 0.2 & 48.5 & 10.4 & 60.7 & 7.9 & 0.7 & 69.3 & 19.8 & 62.3 & 11.1 & 3.7 & 77.1 & 30.7 \\
\hline$P$ value & 0.17 & 0.09 & 0.71 & 0.11 & 0.21 & 0.01 & 0.35 & 0.91 & 0.01 & 0.05 & 0.01 & 0.12 & 0.63 & 0.01 & 0.19 \\
\hline Significance $^{\mathrm{y}}$ & NS & NS & NS & NS & NS & $*$ & NS & NS & $* *$ & NS & $* *$ & NS & NS & $* *$ & NS \\
\hline Regression $^{\mathrm{x}}$ & - & - & - & - & - & Q & - & - & Q & - & Q & - & - & Q & - \\
\hline$r^{2}$ & - & - & - & - & - & 0.45 & - & - & 0.44 & - & 0.48 & - & - & 0.47 & - \\
\hline Optimum rate & - & - & - & - & - & 160 & - & - & 160 & - & 159 & - & - & 173 & - \\
\hline & & & & & & & 2015 & & & & & & & & \\
\hline 0 & 13.1 & 3.0 & 0.6 & 16.7 & 10.0 & 15.1 & 3.6 & 1.6 & 20.2 & 12.2 & 15.1 & 5.3 & 4.5 & 24.9 & 14.1 \\
\hline 56 & 14.1 & 3.4 & 0.8 & 18.4 & 10.9 & 15.5 & 5.2 & 2.0 & 22.6 & 13.4 & 15.7 & 5.8 & 4.4 & 25.8 & 15.4 \\
\hline 93 & 15.7 & 3.3 & 1.3 & 20.3 & 11.0 & 16.8 & 4.5 & 2.9 & 24.1 & 13.0 & 17.1 & 7.1 & 5.0 & 29.1 & 15.0 \\
\hline 149 & 11.3 & 2.3 & 0.7 & 14.3 & 6.5 & 15.2 & 4.6 & 3.7 & 23.5 & 8.6 & 16.2 & 10.1 & 10.3 & 36.5 & 11.4 \\
\hline 186 & 9.7 & 2.5 & 0.7 & 12.9 & 7.0 & 13.5 & 5.7 & 4.1 & 23.2 & 9.4 & 14.2 & 10.3 & 9.8 & 34.3 & 10.6 \\
\hline 223 & 15.9 & 3.0 & 1.1 & 20.0 & 7.2 & 18.5 & 5.6 & 4.5 & 28.7 & 8.9 & 19.4 & 8.9 & 11.9 & 40.2 & 11.8 \\
\hline$P$ value & 0.15 & 0.85 & 0.77 & 0.18 & 0.59 & 0.47 & 0.32 & 0.003 & 0.17 & 0.62 & 0.45 & 0.03 & 0.002 & 0.02 & 0.70 \\
\hline Significance $^{\mathrm{y}}$ & NS & NS & NS & NS & NS & NS & NS & $* *$ & NS & NS & NS & $*$ & $* *$ & $*$ & NS \\
\hline Regression $^{\mathrm{x}}$ & - & - & - & - & - & - & - & $\mathrm{L}$ & - & - & - & LP & $\mathrm{L}$ & LP & - \\
\hline$r^{2}$ & - & - & - & - & - & - & - & 0.60 & - & - & - & 0.47 & 0.58 & 0.43 & - \\
\hline Optimum rate & - & - & - & - & - & - & - & - & - & - & - & 153 & - & 178 & - \\
\hline
\end{tabular}

${ }^{\mathrm{z}} \mathrm{XL}=$ extra-large $(>7 \mathrm{~cm}), \mathrm{L}=$ large $(6.4$ to $7.1 \mathrm{~cm}), \mathrm{M}=$ medium $(5.7$ to $6.4 \mathrm{~cm}), \mathrm{T}=$ total marketable, $\mathrm{U}=$ unmarketable.

${ }_{\mathrm{NS}}, * * *$ Nonsignificant or significant at $P<0.05$ and 0.01 , respectively.

${ }^{\mathrm{x}} \mathrm{Q}=$ quadratic; $\mathrm{L}=$ linear; $\mathrm{LP}=$ linear-plateau; $r^{2}=$ coefficient of determination.


with different potassium $(\mathrm{K})$ rates in 2014 and 2015 winter seasons in Homestead, FL.

\begin{tabular}{|c|c|c|c|c|c|}
\hline \multirow[b]{2}{*}{$\mathrm{K}$ rate $\left(\mathrm{kg} \cdot \mathrm{ha}^{-1}\right)$} & \multirow[b]{2}{*}{ Deformation $^{z}(\mathrm{~mm})$} & \multicolumn{2}{|c|}{ Exterior color ${ }^{\mathrm{y}}$} & \multirow[b]{2}{*}{$\mathrm{pH}$} & \multirow[b]{2}{*}{ TSS $\left({ }^{\circ}\right.$ Brix } \\
\hline & & $2014^{x}$ & 2015 & & \\
\hline$\overline{0}$ & 2.7 & 5.1 & 4.5 & 4.3 & 3.8 \\
\hline 56 & 2.4 & 4.9 & 4.9 & 4.3 & 3.7 \\
\hline 93 & 2.6 & 5.4 & 5.0 & 4.4 & 3.7 \\
\hline 149 & 2.8 & 5.1 & 5.6 & 4.3 & 3.7 \\
\hline 186 & 2.6 & 4.6 & 4.8 & 4.4 & 3.8 \\
\hline 223 & 2.6 & 5.1 & 5.0 & 4.3 & 3.8 \\
\hline$P$ value & 0.51 & 0.15 & 0.003 & 0.18 & 0.08 \\
\hline Significance $^{\mathrm{w}}$ & NS & NS & $* *$ & NS & NS \\
\hline Regression $^{\mathrm{v}}$ & - & - & $\mathrm{Q}$ & - & - \\
\hline$r^{2}$ & - & - & 0.47 & - & - \\
\hline Optimum rate & - & - & 138 & - & - \\
\hline
\end{tabular}

${ }^{\mathrm{z}}$ Firmness test: very firm $\leq 0.7 \mathrm{~mm}$, firm $\leq 1.4 \mathrm{~mm}$, medium $\leq 2.1 \mathrm{~mm}$, soft $\leq 2.8 \mathrm{~mm}$, and very soft $>2.8 \mathrm{~mm}$.

${ }^{\mathrm{y}}$ Exterior color: $1=$ green, $2=$ breaker, $3=$ turning, $4=$ pink, $5=$ light red, and $6=$ red.

${ }^{\mathrm{x}}$ When interaction effect between year and $\mathrm{K}$ rate was significant, data were analyzed separately for each year.

${ }^{\mathrm{w}} \mathrm{NS}, * *$ Nonsignificant or significant at $P<0.01$, respectively.

${ }^{\mathrm{v}} \mathrm{Q}=$ quadratic; $r^{2}=$ coefficient of determination. 
growth. At 60 DAT of both years, the LTKC increased linearly with increasing $\mathrm{K}$ rates, which was consistent with the results reported by Locascio et al. (1997). However, deficient levels of LTKC were detected in plants with $\mathrm{K}$ rates below $149 \mathrm{~kg} \cdot \mathrm{ha}^{-1}$ at 95 DAT in 2014. Similarly, Csizinszky (1999) reported that $\mathrm{K}$ concentrations were lower than $20 \mathrm{~g} \cdot \mathrm{kg}^{-1}$ in tomato shoots at 102 DAT with $180 \mathrm{~kg} \cdot \mathrm{ha}^{-1}$ or lower in acid-mineral soils containing $56 \mathrm{mg} \cdot \mathrm{kg}^{-1}$ of $\mathrm{K}$. Potassium rate of $223 \mathrm{~kg} \cdot \mathrm{ha}^{-1}$ resulted in higher LTKC than the sufficient value at 60 DAT of both years and at 95 DAT in 2015, indicating potentially luxury consumption of $\mathrm{K}$ and overfertilization.

Previous researches showed that there was a high demand for $\mathrm{K}$ and rapid redistribution of $\mathrm{K}$ from leaf and stem to fruit during fruit production (Huang and Snapp, 2009; Tapia and Gutierrez, 1997). Thus, even though the initial soil $\mathrm{K}$ was sufficient to support vegetative growth, significant difference in fruit biomass was observed at 95 DAT in both years. According to Mehlich-3 soil-test interpretation for acid-mineral soils in Florida, the STK level in this study was categorized as high, with which crop-yield response to $\mathrm{K}$ fertilization was not expected. Nevertheless, K application resulted in significant TSMY increases for both years. Therefore, the Mehlich-3 soil-test interpretation for acid-mineral soils was not practical for calcareous soils in Florida. If the ABDTPA soil-test interpretation for Colorado calcareous soils is instead adopted, the preplant STK level during both years will be ranked as medium $\left(61-120 \mathrm{mg} \cdot \mathrm{kg}^{-1}\right.$, Soltanpour, 1985), which will be reasonable based on the responses of TSMY. In Florida acid-mineral soil with low-level STK (34 mg. $\mathrm{kg}^{-1}$ ), Locascio et al. (1997) showed that with preplant broadcasting K on bed and drip irrigation, maximum TSMY was produced at $150 \mathrm{~kg} \cdot \mathrm{ha}^{-1}$ of $\mathrm{K}$. However, Santos (2013) found that $\mathrm{K}$ rates of 336 to $448 \mathrm{~kg} \cdot \mathrm{ha}^{-1}$ were required with preplant band application in bed and subsurface irrigation with $<20 \mathrm{mg} \cdot \mathrm{kg}^{-1}$ of STK. Consequently, besides preplant STK level, tomato yield responses to K rates predominantly depended on irrigation type and $\mathrm{K}$ fertilizer application method. In this study, with drip irrigation and combining preplant band application and fertigation in calcareous soils, optimum $\mathrm{K}$ rates based on TSMY were predicted to be 173 to $178 \mathrm{~kg} \cdot \mathrm{ha}^{-1}$, which were similar to the results of Locascio et al. (1997).

Increasing $\mathrm{K}$ rate to $159 \mathrm{~kg} \cdot \mathrm{ha}^{-1}$ significantly improved total season extra-large fruit yield in 2014. Although total season extralarge fruits were not significantly affected in 2015 , total season large-fruit yield increased linearly with increasing $\mathrm{K}$ rate to $153 \mathrm{~kg} \cdot \mathrm{ha}^{-1}$. These results were in support of the conclusion that adequate $\mathrm{K}$ improved fruit size, as stated by Havlin et al. (2014). As demonstrated by the regression models in the first and second combined harvest and totalseason harvest of both years, the optimum K rates were between 153 and $178 \mathrm{~kg} \cdot \mathrm{ha}^{-1}$, indicating that the rate above $178 \mathrm{~kg} \cdot \mathrm{ha}^{-1}$ will not positively influence marketable yield. A similar yield response to $\mathrm{K}$ rates was reported by Liu et al. (2011), who found that further increases of $\mathrm{K}$ from $200 \mathrm{~kg} \cdot \mathrm{ha}^{-1}$ had no effect on TSMY for processing tomatoes grown on loamy sand soil with 133 to $193 \mathrm{mg} \cdot \mathrm{kg}^{-1}$ of ammonium acetate-extracted $\mathrm{K}$.

Javaria et al. (2012) showed a positive linear relationship between $\mathrm{K}$ rates and surface redness and firmness of pot-grown tomatoes in Pakistan as well as a significant decrease in fruit $\mathrm{pH}$ from 4.9 to 4.6 with increasing $\mathrm{K}$ rates. Furthermore, $\mathrm{K}$ rates of $400 \mathrm{~kg} \cdot \mathrm{ha}^{-1}$ resulted in a significant increase in tomato TSS content from 4.5 to 4.8 with drip irrigation compared with non-K application (Liu et al., 2011), and the TSS increased from 5 to 7 with increased $\mathrm{K}$ rates as high as $311 \mathrm{~kg} \cdot \mathrm{ha}^{-1}$ (Javaria et al., 2012). However, Hartz et al. $(1999,2005)$ reported that neither $\mathrm{K}$ dry-fertilizer application rates as high as $370 \mathrm{~kg} \cdot \mathrm{ha}^{-1}$ nor fertigation of 800 $\mathrm{kg} \cdot \mathrm{ha}^{-1}$ significantly improved TSS content of processing tomato in California. In this study, the only significant difference was found in the exterior color of tomato in 2015. The lack of response of fruit firmness, $\mathrm{pH}$, and TSS content to $\mathrm{K}$ rates might be due to the sufficient soil initial $\mathrm{K}$ level to maintain fruit quality. Jifon and Lester (2009) found that a high soil $\mathrm{K}$ level was unable to improve muskmelon (Cucumis melo) quality on calcareous soils because of uptake competition between $\mathrm{K}, \mathrm{Ca}$, and Mg. Also, Hartz et al. (1999) indicated that tomato fruit-quality parameters (exterior color disorders, yellow shoulder, internal white tissue, and TSS) were correlated better with $\mathrm{K} / \mathrm{Mg}$ ratios than with STK alone. Furthermore, tomato qualities might be predominately influenced by tomato variety, irrigation method, or other factors, as revealed by Hartz et al. (2001). Thus, more studies need to be conducted in the future to support these results about postharvestquality parameters.

\section{Conclusions}

Fresh market tomatoes were grown on a calcareous soil with 78 to $82 \mathrm{mg} \cdot \mathrm{kg}^{-1}$ (medium level) of preplant AB-DTPAextracted $\mathrm{K}$ and multiple $\mathrm{K}$ rates during the winter seasons of 2014 and 2015 in Homestead, FL. Potassium rates below $149 \mathrm{~kg} \cdot \mathrm{ha}^{-1}$ resulted in deficient levels of LTKC at 95 DAT in 2014. Tomato fruit dry weight biomasses at 95 DAT were predicted by linearplateau models with critical $\mathrm{K}$ rates of 130 and $147 \mathrm{~kg} \cdot \mathrm{ha}^{-1}$ in 2014 and 2015, respectively. Responses of total marketable yield in the first harvest to $\mathrm{K}$ rates were not significant in both years. Optimum $\mathrm{K}$ rates for TSMY were estimated to be 173 and $178 \mathrm{~kg} \cdot \mathrm{ha}^{-1}$ in 2014 and 2015, respectively. Tomato-fruit firmness, $\mathrm{pH}$, and TSS content were not significantly influenced by $\mathrm{K}$ rates in both years. Therefore, $178 \mathrm{~kg} \cdot \mathrm{ha}^{-1}$ could be considered an adequate $\mathrm{K}$ rate for growing drip-irrigated fresh market tomatoes on calcareous soils with a medium level of AB-DTPAextracted $\mathrm{K}$.

\section{Literature Cited}

Barten, J.H.M., J.W. Scott, N. Kedar, and Y. Elkind. 1992. Low temperatures induce rough blossom-end scarring of tomato fruit during early flower development. J. Amer. Soc. Hort. Sci. 117:298-303

Bose, P., D. Sanyal, and K. Majumdar. 2006. Balancing potassium, sulfur, and magnesium for tomato and chili grown on red lateritic soil. Better Crops Plant Food 90:22-24.

Carranza, J.F., S.K. O’Hair, H.H. Bryan, G.J. Hochmuth, and E.A. Hanlon. 1996. Nitrogen and potassium fertigation and cultivar effects on tomato yield and graywall in Dade County. Proc. Fla. Tomato Inst. 108:35-39.

Csizinszky, A. 1999. Yield response of polyethylene mulched tomato to potassium source and rate on sand. J. Plant Nutr. 22:669-678.

Frasca, A.C. and M. Ozores-Hampton. 2014. Effects of plant population and breeding lines on fresh-market, compact growth habit tomatoes growth, flowering pattern, yield, and postharvest quality. HortScience 49:1529-1536.

Freeman, J.H., E.J. McAvoy, N. Boyd, P.J. Dittmar, M. Ozores-Hampton, H.A. Smith, G.E. Vallad, and S.E. Webb. 2014a. Tomato production, p. 183-204. In: G.E. Vallad, J.H. Freeman, and P.J. Dittmar (eds.). 2014-2015 Vegetable and small fruit production handbook of Florida. Vance Publishers, Lenexa, KS.

Freeman, J.H., G.E. Vallad, G. Liu, E.H. Simonne, G.J. Hochmuth, M.D. Dukes, L. Zotarelli, J.W. Noling, D.A. Botts, P.J. Dittmar, and S.A. Smith. 2014b. Vegetable production in Florida, p. 1-6. In: G.E. Vallad, J.H. Freeman, and P.J. Dittmar (eds.). 2014-2015 Vegetable and small fruit production handbook of Florida. Vance Publishers, Lenexa, KS.

Hartz, T.K., C. Giannini, R.O. Miller, and E.M. Miyao. 2002. Estimating soil potassium availability for processing tomato production. Commun. Soil Sci. Plan. 33:1389-1400.

Hartz, T.K., P.R. Johnstone, D.M. Francis, and E.M. Miyao. 2005. Processing tomato yield and fruit quality improved with potassium fertigation. HortScience 40:1862-1867.

Hartz, T.K., G. Miyal, R.J. Mullen, M.D. Cahn, J. Valencia, and K.L. Brittan. 1999. Potassium requirements for maximum yield and quality of processing tomato. J. Amer. Soc. Hort. Sci. 124:199-204.

Hartz, T.K., E.M. Miyao, R.J. Mullen, and M.D. Cahn. 2001. Potassium fertilization effects on processing tomato yield and fruit quality. Acta Hort. 542:127-133.

Hatfield, J.L. and J.H. Prueger. 2015. Temperature extremes: Effect on plant growth and development. Weather Clim. Extrem. 10:4-10.

Havlin, J.L., S.L. Tisdale, W.L. Nelson, and J.D. Beaton. 2014. Potassium, p. 223-238. In: Soil fertility and fertilizers: An introduction to nutrient management. Pearson Education Inc., Upper Saddle River, NJ.

Hochmuth, G., D. Maynard, C. Vavrina, E. Hanlon, and E. Simonne. 2012. Plant tissue analysis and interpretation for vegetable crops in Florida. Univ. Florida, Inst. Food Agr. Sci., Electronic Data Info. Source. HS964. 10 July 2016. $<$ http://edis.ifas.ufl.edu/ep081 $>$.

Huang, J. and S.S. Snapp. 2009. Potassium and boron nutrition enhance fruit quality in Midwest fresh market tomatoes. Commun. Soil Sci. Plan. 40:1937-1952. 
Javaria, S., M.Q. Khan, and I. Bakhsh. 2012. Effect of potassium on chemical and sensory attributes of tomato fruit. J. Anim. Plant Sci. 22:1081-1085.

Jifon, J.L. and G.E. Lester. 2009. Foliar potassium fertilization improves fruit quality of fieldgrown muskmelon on calcareous soils in south Texas. J. Sci. Food Agr. 89:2452-2460.

Li, Y. 2015. Calcareous soils in Miami-Dade County. Univ. Florida Inst. Food Agr. Sci., Electronic Data Info. Source. SL183. 20 May 2016. <http://edis.ifas.ufl.edu/tr004>.

Liu, K., T.Q. Zhang, C.S. Tan, and T. Astatkie. 2011. Responses of fruit yield and quality of processing tomato to drip-irrigation and fertilizers phosphorus and potassium. Agron. J. 103:1339-1345.

Locascio, S.J., G.J. Hochmuth, S.M. Olson, R. C. Hochmuth, A.A. Csizinszky, and K.D. Shuler. 1997. Potassium source and rate for polyethylene-mulched tomatoes. HortScience 32:1204-1207.

Mylavarapu, R.S., W. d'Angelo, N. Wilkinson, and D. Moon. 2014. UF/IFAS extension soil testing laboratory analytical procedures and training manual. Univ. Florida, Inst. Food Agr. Sci., Electronic Data Info. Source. 10 July 2016. $<$ http://edis.ifas.ufl.edu/ss312>.
Olson, S.M. and J. Freeman. 2016. Physiological, nutritional, and other disorders of tomato fruit. Univ. Florida, Inst. Food Agr. Sci., Electronic Data Info. Source. HS954. 10 July 2016. $<$ http://edis.ifas.ufl.edu/hs200>.

Ozores-Hampton, M. and G. McAvoy. 2015. Blossom drop, reduced fruit set, and post-pollination disorders in tomato. Univ. Florida, Inst. Food Agr. Sci., Electronic Data Info. Source. HS1195. 9 Feb. 2017. <http://edis.ifas.ufl.edu/hs1195>.

Ozores-Hampton, M., E. Simonne, F. Roka, K. Morgan, S. Sargent, C. Snodgrass, and E. McAvoy. 2012a. Nitrogen rates effects on the yield, nutritional status, fruit quality, and profitability of tomato grown in the spring with subsurface irrigation. HortScience 47:1129-1135.

Ozores-Hampton, M., C. Snodgrass, and K. Morgan. 2012b. Effects of potassium rates in yield, fruit quality, plant biomass and uptake on mature-green tomatoes in seepage irrigation. Fla. Tomato Inst. Proc.528:17-20.

Santos, B.M. 2013. Effects of preplant potassium sources and rates for tomato production. HortTechnology 23:449-452.

Soltanpour, P.N. 1985. Use of ammonium bicarbonate DTPA soil test to evaluate elemental availability and toxicity. Commun. Soil Sci. Plan. 16:323-338.
Tapia, M.L. and V. Gutierrez. 1997. Distribution pattern of dry weight, nitrogen, phosphorus, and potassium through tomato ontogenesis. J. Plant Nutr. 20:783-791.

U.S. Department of Agriculture (USDA). 1996. Soil survey of Dade County Area, Florida. USDA, Natural Resources Conservation Service, Washington, DC. 30 May 2016. <http://www. nrcs.usda.gov/Internet/FSE_MANUSCRIPTS/ florida/FL686/0/Dade.pdf $>$.

U.S. Department of Agriculture (USDA). 1997. United States standards for grades of fresh tomatoes. USDA, Agriculture Marketing Service, Washington, DC. 30 May 2016. $<$ https://www.hort.purdue.edu/prod_quality/ quality/tomatfrh.pdf $>$.

U.S. Department of Agriculture (USDA). 2016. 2015 State agriculture overview Florida. USDA, National Agricultural Statistics Service, Washington, DC. 30 May 2016. <https:// www.nass.usda.gov/Quick_Stats/Ag_Overview/ stateOverview.php?state=FLORIDA $>$.

Zhu, Q., M. Ozores-Hampton, and Y. Li. 2016. Comparison of Mehlich-3 and ammonium bicarbonate-DTPA for the extraction of phosphorus and potassium in calcareous soils from Florida. Commun. Soil Sci. Plan. 47:23152324 